\title{
Optimization of Slice Thickness, Drying Method, and Temperature of Turmeric Rhizome (Curcuma Longa L.) Based on Water Content and Functional Compound Degradation
}

\author{
Pirim Setiarso $^{1}$, Nita Kusumawati ${ }^{2}$ \\ Department of Chemistry \\ Universitas Negeri Surabaya \\ Surabaya, Indonesia \\ 11pirimsetiarso@unesa.ac.id, 2nkusumawati82@yahoo.com
}

\author{
Rusijono $^{3}$ \\ Department of Education \\ Universitas Negeri Surabaya \\ Surabaya, Indonesia \\ ${ }^{3}$ rusijonorusijono@gmail.com
}

\author{
Supari Muslim ${ }^{4}$ \\ Department of Electrical Engineering \\ Universitas Negeri Surabaya \\ Surabaya, Indonesia \\ ${ }^{4}$ suparimuslim@gmail.com
}

\begin{abstract}
The research of oven-based drying technology on the production process of turmeric rhizome (Curcuma Longa $\mathbf{L}$.) with thickness 0.15 and $0.30 \mathrm{~cm}$ have been. A number of parameters, such as slicing thickness, drying methods and temperatures are optimized, to achieve water and functional compounds (essential oils, curcuminoids, curcumin, demethoxycurcumin, bis-demethoxycurcumin and polysaccharides) content that meet the standards. The results of applying oven-based drying technology to turmeric and white turmeric were investigated at four temperatures $(70,85,100,115$ ${ }^{\circ} \mathrm{C}$ ) and compared with conventional drying using sunlight (with and without black cloth). Low water content of turmeric and white turmeric was observed on drying results using an oven with a temperature of $115{ }^{\circ} \mathrm{C}$, but with a higher degree of functional compound degradation compared with conventional drying results, with and without black fabric intermediates. Based on water content, the optimum drying results are obtained from oven-based drying with a temperature of $115^{\circ} \mathrm{C}$ and a slice thickness of $0.15 \mathrm{~cm}$. The evaluation results of the functional compound levels using HPLC under optimum conditions showed significant differences between conventional and oven-based drying results. Although the essential oil content of turmeric and white turmeric simplicia in this study is still above that required by Materia Med Indonesia, which is $1.5 \%$, but of all the drying methods tested, oven-based drying is capable of producing the simplified product with the most close to oil content $1.5 \%$ compared with conventional drying. Thus, oven technology can be used as an alternative method for drying of rhizome to produce turmeric and white turmeric simplicia with optimum quality as well as lower process time and energy.
\end{abstract}

Keywords- Rhizome; turmeric; white turmeric; simplicia; oven; technology

\section{INTRODUCTION}

Turmeric is one type of spice that belongs to the Zingiberaceae family which is generally bred from Curcuma longa rhizome [1]. The bright yellow characteristic obtained from turmeric is primarily produced by the performance of the fat-soluble polyphenolic pigment commonly referred to as curcuminoid which includes curcumin (C1), demethoxy curcumin (C2) and bis-demethoxy curcumin (C3) [2]. Turmeric and its commercial extract are very popular throughout the world for various industries as spices and preservatives in the food industry, as well as dyes in the food and textile industry [1][3]. Turmeric is also reported to have antioxidant and antimicrobial effects [3-4] as well as is a potentially high biological material as a cure for cancer, cardiovascular, inflammatory and Alzheimer diseases [2, 5].

White turmeric (Curcuma zedoria Rosc.) is one kind of Zingiberaceae family is no less important in traditional medicine and the drug industry. White turmeric has the main ingredients in the form of essential oil with an assortment of monoterpenes and sesquiterpenes, curcuminoids, and polysaccharides. Pharmacological activity demonstrated antimicrobial effects [6], anti-inflammatory, anti-cancer, hepatoprotective and insecticides. The compounds curcuminoid such as curcumin, demethoxy curcumin and bisdemethoxy curcumin is a bioactive component in the genus Curcuma who are known to have a cytotoxic effect against OVCAR-3 (Human Ovarian Cancer Cells) and is traditionally used in the treatment of cervical cancer [7]. While the polysaccharide compounds binds proteins and they can be 
isolated with white turmeric are reported to have antitumor properties in Ehrlich ascites (mouse tumors) [8].

The management of post-harvesting must be highly considered because its effect on the quality of the products. Quality and safety of bio-farm products, one of which is simplicia, is closely related to the quality of raw materials, post-harvesting handling, and processing technology. Postharvesting management technologies include selecting, washing, drying [9-12], packaging, labeling and storage, before being marketed, both on fresh conditions and after further processing. However, as far as the knowledge of authors the detailed report on Standard Operating Procedure (SOP) of post-harvest preparation of products, especially in the form of simplicia, with quality as per the standards required by Materia Med Indonesia [12] does not exist.

In previous reports [12] it has been reported the effect of washing time, slice thickness, drying method and temperature on the quality of ginger and red ginger rhizome. The results showed that the best quality turmeric and white turmeric simplicia, according to Materia Med Indonesia prerequisites, was obtained from a production process involving washing for 1 minute, slice thickness of $0.15 \mathrm{~cm}$, and drying using oven at $115^{\circ} \mathrm{C}$. Further, to get the effect of these four factors on the quality of the other rhizome which is also a kind of local potency of Indonesia, in this research have been studied influence of washing time, slice thickness, method and temperature of drying to water and functional compound content of turmeric and white turmeric simplicia.

Based on its usefulness, in this study, the contents of turmeric and white turmeric functional compounds include: (1) essential oils; (2) curcuminoid; (3) curcumin; (4) demethoxy curcumin, and (5) bis-demethoxy curcumin, becoming the indicator for the achievement of the turmeric and white turmeric simplicia quality.

\section{MATERIAL AND METHOD}

\section{A. Material}

The main raw materials used in this research are turmeric and white turmeric rhizome. Optimization and standardization of post-harvesting management of turmeric and white turmeric rhizomes was carried out using a number of pre-published equipment [12], including washers (artificial) required for optimization of washing time using hot plate magnetic stirrer plate (NESCO Lab MS-H280) as a motor that produces a whirlpool to reduce contaminants, slicing machine (Bosch MUZ4DS3) capable of performing 60 grams/min with a thickness of $0.15 \mathrm{~cm}$ and $0.30 \mathrm{~cm}$; the J-LabTech LDO-030E (Daihan LabTech Ltd. Co.) drying machine which has a heating temperature range of $50{ }^{\circ} \mathrm{C}-250{ }^{\circ} \mathrm{C}$ and a drying time capacity of up to 60 minutes for optimization of rhizomes drying.

\section{B. Manufacturing of turmeric and white turmeric simplicial}

Post-harvest handling of turmeric and white turmeric rhizome is done through three main stages covering washing, slicing, and drying. To obtain optimum quality, it has been done washing with varying duration, 1 - 3 minutes. After that, rhizome through the slicing thickness optimazation stage to obtain a thickness which capable to producing water and functional group content fulfill the standard set by Materia Med Indonesia. For this purpose, the applied slice thickness is $0.15 \mathrm{~cm}$ and $0.30 \mathrm{~cm}$. The rhizomes were then dried by using 3 (three) drying methods, which was by sunlight, sunlight with black cloth as an intermediary, and oven. To determine the effect of drying temperature, the drying process using the oven is applied at a number of different temperatures including 70 ${ }^{\circ} \mathrm{C}$; $85{ }^{\circ} \mathrm{C}$; $100{ }^{\circ} \mathrm{C}$; and $115{ }^{\circ} \mathrm{C}$. The drying process is accomplished without the reversal of the sample, and is immediately stopped after the constant mass of samples is obtained.

\section{Turmeric and white turmeric water content analysis}

The water content of turmeric and white turmeric simplicia is evaluated with reference to AOAC 927.05 (AOAC, 2000).

\section{Turmeric and white turmeric functional compound content analysis}

Analysis of functional compound content of turmeric and white turmeric simplicia was carried out by the following procedure: (1) essential oil analysis performed by Stahl distillation, (2) curcuminoid, curcumin, demethoxy curcumin and bis-demethoxy curcumin analysis performed with liquid chromatography (LC) (Agilent 1290 Infinity) and STM columns (Agilent 1290 Infinity). Meanwhile, polysaccharide analysis was performed with UV-Visible Spectrophotometer (Pharmaspec UV-1700) at maximum wavelength ( $\lambda \max 490$ $\mathrm{nm})$.

\section{RESULT AND DISCUSSION}

\section{A. The influence of washing time against turmeric and white turmeric water and functional compound content}

Washing time is one of the variables in the post-harvest processing of rhizome that affect the quality of the product, especially on the content of its functional compounds. Rhizome washes with appropriate times will result in a simplicia product with minimal contaminant and quality that meet the herbal product standards established by Materia Med Indonesia [12]. Thus, the production process will not only produce products with higher functional compound content but also longer shelf life which is directly related to a low water content in rhizome products. In Fig. 1, appears the molecular structure of curcumin, desmethoxy curcumin, and bis-desmethoxy curcumin contained in curcuminoids in rhizome of turmeric and white turmeric. In Fig. 1, the difference in molecular between $\mathrm{C}_{21} \mathrm{H}_{20} \mathrm{O}_{6}$ for curcumin, $\mathrm{C}_{20} \mathrm{H}_{17} \mathrm{O}_{5}$ for desmethoxy curcumin, and $\mathrm{C}_{19} \mathrm{H}_{14} \mathrm{O}_{4}$ for bisdesmethoxy curcumin. In Table I was presented drying time and water content of dry turmeric and white turmeric simplicia obtained from the application of washing stages for 1-3 minutes. In Table I it is apparent that an increase in washing time applied to the producing process of turmeric and white turmeric simplicia will occur as the longer drying time is applied and the higher the water content it contains. In the 
process of turmeric simplicia producing, the simplicia with the lowest water content of $13.8 \%$ was obtained from washing for 1 minute with a drying time of 380 minutes. Meanwhile, in the process of producing white turmeric simplicia, the product with the lowest water content of $10.0 \%$ was obtained from washing for 1 minute with 400 minute drying time. Thus, it can be said that at the same time of washing, the turmeric contains a higher percentage of water content compared to white turmeric. The increased application of washing time on turmeric and white turmeric simplicia production has induced an increase in the quantity of water diffusing into the inner layer of material so that longer drying time is required.

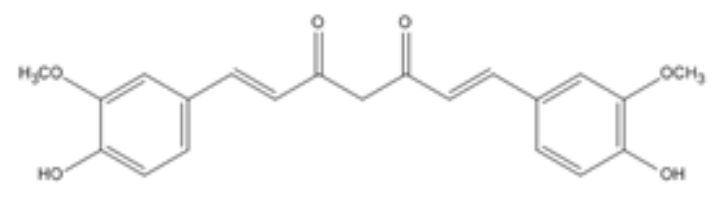

(a)

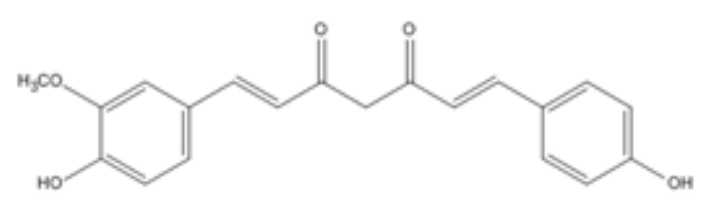

(b)

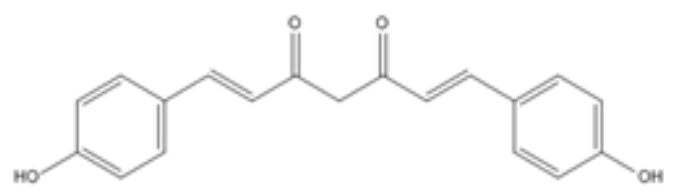

(c)

Fig. 1. A molecular structure of: (a) curcumin; (b) desmethoxy curcumin; and (c) bis-desmethoxy curcumin

TABLE I. DRYING TIME OF TURMERIC AND WHITE TURMERIC SIMPLICIA RESULTED FROM WASHING TIME OPTIMIZATION

\begin{tabular}{|c|c|c|c|c|c|c|c|}
\hline \multirow[t]{2}{*}{ No } & \multirow[t]{2}{*}{$\begin{array}{c}\text { Simplicia's } \\
\text { Type }\end{array}$} & \multicolumn{3}{|c|}{$\begin{array}{l}\text { Drying Time Resulted } \\
\text { from Washing Time } \\
\text { (minute) }\end{array}$} & \multicolumn{3}{|c|}{$\begin{array}{c}\text { Water Content (\%) } \\
\text { Resulted from } \\
\text { Washing Time } \\
\text { (minute) }\end{array}$} \\
\hline & & 1 & 2 & 3 & 1 & 2 & 3 \\
\hline 1 & Turmeric & 370 & 380 & 400 & 13.8 & 13.8 & 15.0 \\
\hline 2 & $\begin{array}{l}\text { White } \\
\text { turmeric }\end{array}$ & 400 & 410 & 440 & 10.0 & 14.5 & 14.8 \\
\hline
\end{tabular}

Note:

1. Sliced thickness of $0.15 \mathrm{~cm}$

2. Drying process using oven $100{ }^{\circ} \mathrm{C}$

3. Drying chamber: $15 \mathrm{~cm} \times 6.5 \mathrm{~cm} \times 4 \mathrm{~cm}$

4. Simplicia's mass of $60 \mathrm{~g}$

In addition, to evaluate the influence of washing time on the production of turmeric and white turmeric simplicia, a functional compound content analysis on the resulting simplicia product was performed. In the analysis result shown by Table II, it is clear that there is a decrease in the functional compound content of turmeric and white turmeric simplicia products along with the application of increased washing time. This is due to the solubility of specific functional compounds in simplicia, both turmeric and white turmeric in water used for washing, albeit on a small scale. The decrease of functional compound content of turmeric and white turmeric simplicia produced from washing time variation did not occur significantly. The low decrease of the functional compound content, especially curcuminoid type of both simplicia products, are more due to the relatively low solubility of the corresponding functional compounds in water.

TABLE II. FUNCTIONAL COMPOUND CONTENT OF TURMERIC AND WHITE TURMERIC SIMPICLIAS RESULTED FROM WASHING TIME OPTIMIZATION

\begin{tabular}{|c|c|c|c|c|c|c|}
\hline \multirow[b]{2}{*}{$\begin{array}{c}\text { Simplicias Type \& } \\
\text { Washing Time (minute) }\end{array}$} & \multicolumn{6}{|c|}{ Functional Compound Content (\%) } \\
\hline & 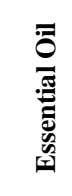 & 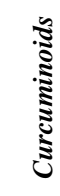 & 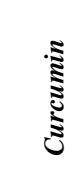 & 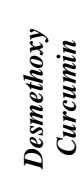 & 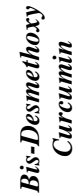 & 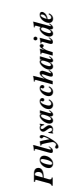 \\
\hline \multicolumn{7}{|c|}{ Turmeric } \\
\hline 1 minute & 3.40 & 2.42 & 64.81 & 12.86 & 3.01 & 0 \\
\hline 2 minute & 3.37 & 1.94 & 63.05 & 12.33 & 2.75 & 0 \\
\hline 3 minute & 2.97 & 1.29 & 56.27 & 11.04 & 2.58 & 0 \\
\hline \multicolumn{7}{|c|}{ White Turmeric } \\
\hline 1 minute & 3.60 & 2.18 & 53.62 & 16.38 & 5.43 & 5.45 \\
\hline 2 minute & 3.59 & 1.86 & 53.42 & 15.56 & 5.02 & 4.90 \\
\hline 3 minute & 3.18 & 1.40 & 46.74 & 14.11 & 4.66 & 4.67 \\
\hline
\end{tabular}

Along with an increase in washing time, curcumin is a functional compound that has the lowest decrease in contents compared with demethoxy curcumin and bis-demethoxy curcumin. This is mainly due to the lowest solubility of curcumin compounds compared to demethoxy curcumin and bis-demethoxy curcumin. The presence of both methyl functional groups as substituents in the curcumin functional compounds have further decreased the solubility of these compounds in water.

The presence of less hydrocarbon groups with lower polarity in the demethoxy curcumin and bis-demethoxy curcumin compounds has increased their solubility in highpolarity solvents such as water. However, when a comparison is made between them, bis-demethoxy curcumin has a higher solubility than demethoxy curcumin in an aqueous solvent. This condition is triggered in the absence of a nonpolar methyl functional group on its molecular structure.

The results of the functional compound analysis of turmeric simplicia showed a specific decrease with the longest washing time, i.e 3 minutes, which was detected decrease in: 
(a) essential oil content, respectively $1 \%$ and $12.67 \%$; (b) curcuminoid, respectively by $19.83 \%$ and $46.69 \%$; (c) curcumin in curcuminoid, respectively $2.72 \%$ and $13.18 \%$; (d) desmethoxy curcumin in the curcuminoid, respectively by $4.12 \%$ and $14.12 \%$; and (e) bis-desmethoxy curcumin, each of $8.78 \%$ and $14.28 \%$ when the washing time applied increases.

The same reduction was also detected in the functional compound contents of white turmeric simplicia that had been through the washing stage for 3 minutes, which was detected decrease in : (a) essential oil content, respectively $0.37 \%$ and $11.67 \%$; (b) curcuminoid, respectively by $14.29 \%$ and $35.73 \%$; (c) curcumin in curcuminoid, respectively $0.37 \%$ and $12.84 \%$; (d) demethoxy curcumin in the curcuminoid, respectively by $5 \%$ and $13.86 \%$; (e) bis-demethoxy curcumin, each of $7.63 \%$ and $14.13 \%$; and (f) polysaccharide, respectively by $10.09 \%$ and $14.40 \%$ when washing time increases. Thus, the decrease in functional compound contents in white turmeric simplicia was found to be lower than turmeric after washing for 3 minutes.

\section{B. The effect of slicing thickness and drying method to simplicia's quality and nutritional content}

In Table 3 and 4 appears the drying time which are $22.38 \% ; 10.09 \%$; and $37.50 \%$ longer of the turmeric simplicia having a thickness of $0.3 \mathrm{~cm}$ compared to $0.15 \mathrm{~cm}$ in a production process which each involves drying out by the sun without, and with an intermediate black cloth and oven with a temperature of $100{ }^{\circ} \mathrm{C}$. The drying time yields dried turmeric simplicia with a water content of $13.8 \%-20.5 \%$. Turmeric simplicia with a thickness of $0.30 \mathrm{~cm}$ shows a water content yield of $26.81 \% ; 48.55 \%$; and $6.67 \%$ higher than those having a thickness of $0.15 \mathrm{~cm}$ at the production stage accompanied by drying by the sun without, and with intermediate black cloth and oven with temperature $100{ }^{\circ} \mathrm{C}$.

Meanwhile, in the producing process of white turmeric simplicia with slice thickness of $0.3 \mathrm{~cm}$, it takes $26.49 \%$; 9.15\%; and $5.17 \%$ longer drying time than the drying process of white turmeric with a thickness of $0.15 \mathrm{~cm}$, each has been through the drying process using sunlight, sunlight with a black cloth intermediate, and an oven with temperature of $100{ }^{\circ} \mathrm{C}$. This longer drying time has resulted in white turmeric simplicia with a water content of $17.3 \% ; 19.3 \%$; and $15.0 \%$ each resulted from drying process by sunlight, sunlight with black fabric intermediates, and an oven at a temperature of $100{ }^{\circ} \mathrm{C}$. The water content of white turmeric simplicia with a thickness of $0.30 \mathrm{~cm}$ is $73.0 \% ; 33.1 \%$; and $1.35 \%$ higher than the simplicia with a sliced thickness of $0.15 \mathrm{~cm}$, each of which is dried by sunlight, sunlight with a black cloth intermediate, and an oven at a temperature of $100{ }^{\circ} \mathrm{C}$.

Meanwhile, the analysis result shows the need of drying time which are 26.49\%; 9.15\%; and $5.17 \%$ longer on the drying of white turmeric simplicia having a thickness of 0.3 $\mathrm{cm}$ rather than $0.15 \mathrm{~cm}$, in drying with sunlight without, and by using a black cloth intermediate, and an oven with temperature of $100{ }^{\circ} \mathrm{C}$. This drying operational condition has induced the formation of white turmeric simplicia with water content of $17.3 \%$; $19.3 \%$; and $15.0 \%$. Water content detected in white turmeric simplicia with a thickness of $0.30 \mathrm{~cm}$ resulting from drying with sunlight without and with intermediate black cloth and oven with temperature $100{ }^{\circ} \mathrm{C}$ is $73.0 \%$; $33.1 \%$; and $1.35 \%$ higher than the thickness of 0.15 $\mathrm{cm}$.

TABLE III. DRYING TIME OF TURMERIC AND WHITE TURMERIC SIMPLICIAS PRODUCT RESULTED FROM SLICE THICKNESS AND DRYING METHOD OPTIMIZATION

\begin{tabular}{|c|c|c|c|c|c|c|}
\hline \multirow{3}{*}{ Simplisia's Type } & \multirow{2}{*}{\multicolumn{3}{|c|}{$\begin{array}{c}\begin{array}{c}\text { Drying Time } \\
\text { (minute) }\end{array} \\
\begin{array}{c}\text { Slice Thickness } \\
0,15 \mathrm{~cm}\end{array}\end{array}$}} & \multirow{2}{*}{\multicolumn{3}{|c|}{$\begin{array}{c}\begin{array}{c}\text { Drying Time } \\
\text { (minute) }\end{array} \\
\text { Slice Thickness } \\
\mathbf{0 , 3 0 ~ c m ~}\end{array}$}} \\
\hline & & & & & & \\
\hline & 总 & 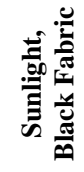 & 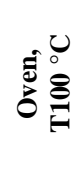 & 总 & 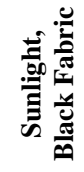 & 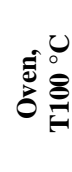 \\
\hline Turmeric & 858 & 1,060 & 400 & 1,050 & 1,167 & 550 \\
\hline White Turmeric & 838 & 1,060 & 580 & 1,060 & 1,157 & 610 \\
\hline
\end{tabular}

Overall, the manufacture of turmeric simplicia products with a sliced thickness of $0.15 \mathrm{~cm}$ using an oven with a temperature of $100{ }^{\circ} \mathrm{C}$ can reduce the drying time to $53.37 \%$ and $62.26 \%$, respectively compared to sunlight drying, without and by using intermediaries black cloth. In line with that, in the producing process of the turmeric simplicia with a thickness of $0.30 \mathrm{~cm}$, drying using an oven with a temperature of $100{ }^{\circ} \mathrm{C}$ can save drying time up to $47.62 \%$ and $52.87 \%$ compared with the same comparison methods.

In accordance with those described in previous publications [12], water becomes one of the important components in food products that are closely related to appearance, texture, and taste. Water content also determines the acceptance of food products. The sensitivity due to the decrease in water content caused by evaporation is influenced by the lack of atmospheric pressure in the surrounding environment and the surface layer structure of the food product.

TABLE IV. WATER CONTENT OF TURMERIC AND WHITE TURMERIC SIMPLICIA RESULTED FROM SLICE THICKNESS AND DRYING METHOD OPTIMIZATION

\begin{tabular}{|c|c|c|c|c|c|c|}
\hline \multirow[b]{3}{*}{ Simplisia's Type } & \multirow{2}{*}{\multicolumn{3}{|c|}{$\begin{array}{c}\text { Water Content (\%) } \\
\text { Slice Thickness } \\
0,15 \mathrm{~cm}\end{array}$}} & \multirow{2}{*}{\multicolumn{3}{|c|}{$\begin{array}{c}\text { Water Content (\%) } \\
\text { Slice Thickness } \\
0,30 \mathrm{~cm}\end{array}$}} \\
\hline & & & & & & \\
\hline & 导 & 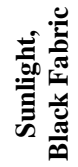 & 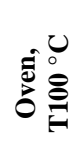 & 㤣 & 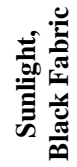 & อ̊ํำ \\
\hline Turmeric & 13.8 & 13.8 & 15.0 & 17.5 & 20.5 & 16.0 \\
\hline White Turmeric & 10.0 & 14.5 & 14.8 & 17.3 & 19.3 & 15.0 \\
\hline
\end{tabular}


TABLE V. FUNCTIONAL COMPOUND CONTENT OF TURMERIC SIMPICLIAS RESULTED FROM SLICING THICKNESS AND DRYING METHOD OPTIMIZATION

\begin{tabular}{|c|c|c|c|c|c|c|}
\hline & \multirow{2}{*}{$\begin{array}{c}\text { Simplicias } \\
\text { Type \& } \\
\text { Drying } \\
\text { Method }\end{array}$} & \multicolumn{5}{|c|}{ Functional Compound Content (\%) } \\
\hline & & 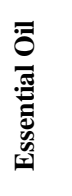 & 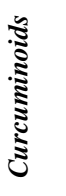 & 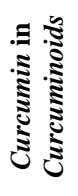 & 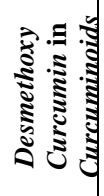 & 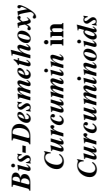 \\
\hline \multirow{2}{*}{ 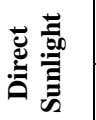 } & $0.15 \mathrm{~cm}$ & 2.88 & 1.26 & 54.22 & 10.58 & 2.11 \\
\hline & $0.30 \mathrm{~cm}$ & 2.90 & 1.28 & 56.05 & 12.06 & 2.45 \\
\hline \multirow{2}{*}{ 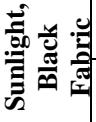 } & $0.15 \mathrm{~cm}$ & 3.18 & 1.87 & 58.23 & 12.88 & 2.54 \\
\hline & $0.30 \mathrm{~cm}$ & 4.38 & 3.88 & 82.56 & 13.02 & 3.56 \\
\hline \multirow{2}{*}{ 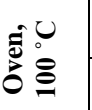 } & $0.15 \mathrm{~cm}$ & 2.69 & 1.22 & 54.18 & 10.46 & 2.08 \\
\hline & $0.30 \mathrm{~cm}$ & 2.70 & 1.24 & 55.12 & 11.27 & 2.42 \\
\hline
\end{tabular}

Drying is one of the oldest preservation techniques in the world and this method is widely used for preserving various agricultural products. By drying, the water activity in the simplicia can be reduced to a minimum level where no deterioration occurs over a definite period of time [13] [14]. The lower water content will have a direct impact on the ease of contamination of food products by fungi and bacteria, reducing the decomposition of the active compound by the enzyme, facilitating further processing, resulting in a more compact structure and longer shelf life [12].

Drying will never replace canning and freezing methods as both methods play a maximum role in preservation so that the taste, appearance, and nutritional value of fresh foods can be maintained, but drying has become the best procedure in the production of delicious and nutritious food. The greatest advantages of dry food products, one of which lies in a minimum storage space needed compared to the results of canning and freezing.

As is well known, in India, it has long been known for the rhizome boiling procedure with an alkaline solution medium before it is dehydrated. However, there is some controversy about the advantages of this procedure and its effect on the turmeric color [15]. Improved product quality and potential loss reduction can only be realized through the use of appropriate drying procedures [14] [15].

In addition, functional compound data of turmeric and white turmeric simplicia, as shown in Table V and Table VI, show the simplicia product of turmeric and white turmeric dried by direct sunlight having a lower material content than the black cloth intermediaries. As previously published [12], the use of high temperatures in the drying process using direct sunlight has also led to higher evaporation levels of the volatile functional compounds in turmeric and white turmeric.
TABLE VI. FUNCTIONAL COMPOUND CONTENT OF WHITE TURMERIC SIMPICLIAS RESULTED FROM SLICING THICKNESS AND DRYING METHOD OPTIMIZATION

\begin{tabular}{|c|c|c|c|c|c|c|c|}
\hline & \multirow[b]{2}{*}{$\begin{array}{c}\text { Simplicias } \\
\text { Type \& } \\
\text { Drying } \\
\text { Method }\end{array}$} & \multicolumn{6}{|c|}{ Functional Compound Content (\%) } \\
\hline & & 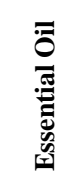 & 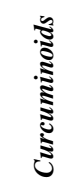 & 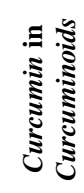 & 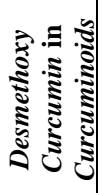 & 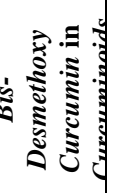 & 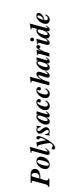 \\
\hline \multirow{2}{*}{ 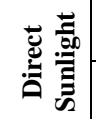 } & $0.15 \mathrm{~cm}$ & 3.10 & 1.35 & 43.72 & 14.56 & 5.10 & 5.66 \\
\hline & $0.30 \mathrm{~cm}$ & 2.98 & 1.80 & 45.01 & 14.86 & 5.12 & 6.01 \\
\hline \multirow{2}{*}{ 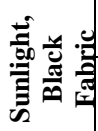 } & $0.15 \mathrm{~cm}$ & 3.36 & 1.84 & 45.05 & 14.91 & 5.11 & 5.68 \\
\hline & $0.30 \mathrm{~cm}$ & 4.81 & 3.96 & 68.19 & 21.48 & 7.86 & 6.18 \\
\hline \multirow{2}{*}{$\begin{array}{ll}0 & 0 \\
0 & 0 \\
0 & \Xi\end{array}$} & $0.15 \mathrm{~cm}$ & 2.81 & 1.30 & 43.51 & 14.47 & 4.35 & 5.60 \\
\hline & $0.30 \mathrm{~cm}$ & 2.85 & 1.31 & 43.80 & 14.58 & 4.14 & 5.62 \\
\hline
\end{tabular}

In addition to the method of drying, the slicing thickness is also a determinant variable of the product quality of turmeric and white turmeric simplicia. This is shown in the data of functional compound content contained in the simplicia with $0.15 \mathrm{~cm}$ and $0.30 \mathrm{~cm}$ sliced thickness, as shown in Table VI and Table VII. The data of the functional compound levels showed that the simplicia product with a sliced thickness of $0.15 \mathrm{~cm}$ had a lower functional compound compared with a thickness of $0.30 \mathrm{~cm}$. This is because the slicing process of turmeric and white turmeric with a lower thickness has resulted in a higher level of damage to the material matrix. Such conditions have facilitated the evaporation of volatile functional compounds from within the material during the drying process. In contrast, higher slice thickness $(0.30 \mathrm{~cm})$ has created significant resistance to the evaporation of functional compounds from within the raw material during the drying process.

\section{The effect of drying temperature to simplicia's quality and nutritional content}

Table VII shows turmeric and white turmeric levels of $16.67 \%$ and $12.67 \%$ for the simplicia produced from drying by oven for 1,610 minutes and 1,820 minutes at $70{ }^{\circ} \mathrm{C}$.

A higher-temperature drying process produces simplicia with lower water content and shorter drying times. The minimum drying process with $80.75 \%$ and $84.62 \%$ shorter drying time on the production process of turmeric and white turmeric simplicia can be achieved through the application of drying procedure at $115^{\circ} \mathrm{C}$. The turmeric and white turmeric simplicia produced from drying at $115{ }^{\circ} \mathrm{C}$ have water content of $13.83 \%$ and $9.50 \%$ after drying process each for 310 and 280 minutes. Data of water content for simplicia of turmeric and white turmeric produced at $70{ }^{\circ} \mathrm{C} ; 85^{\circ} \mathrm{C} ; 100^{\circ} \mathrm{C}$; and $115^{\circ}$ $\mathrm{C}$ are shown in Table VIII. 
TABLE VII. DRYING TIME OF TURMERIC AND WHITE TURMERIC SIMPLICIA PRODUCT RESULTED FROM DRYING TEMPERATURE OPTIMIZATION

\begin{tabular}{|c|c|c|c|c|}
\hline \multirow[b]{2}{*}{ Simplicias Type } & \multicolumn{4}{|c|}{ Drying Time (minute) } \\
\hline & $\begin{array}{l}0 \\
0 \\
0 \\
R \\
R\end{array}$ & $\begin{array}{l}0 \\
0 \\
10 \\
\infty \\
=\end{array}$ & $\begin{array}{l}\text { U } \\
\varnothing \\
\varrho \\
\sigma\end{array}$ & $\begin{array}{l}0 \\
0 \\
= \\
=\end{array}$ \\
\hline Turmeric & 1,610 & 1,540 & 370 & 310 \\
\hline White turmeric & 1,820 & 1,540 & 370 & 280 \\
\hline
\end{tabular}

TABLE VIII. WATER CONTENT OF TURMERIC AND WHITE TURMERIC SIMPLICIA RESULTED FROM DRYING TEMPERATURE OPTIMIZATION

\begin{tabular}{|c|c|c|c|c|}
\hline \multirow[b]{2}{*}{ Simplicia Type } & \multicolumn{4}{|c|}{ Water Content (\%) } \\
\hline & $\mathbb{R}_{0}^{\circ}$ & ט & $\underset{\sigma}{\Xi}$ & $\stackrel{n}{=}$ \\
\hline Turmeric & 16.67 & 15.00 & 13.83 & 13.83 \\
\hline White turmeric & 12.67 & 12.50 & 10.00 & 9.50 \\
\hline
\end{tabular}

To evaluate the effect of temperature on the production of turmeric and white turmeric simplicia, there has been done an analysis of functional compound of simplicia resulting from drying at $70^{\circ} \mathrm{C} ; 85^{\circ} \mathrm{C} ; 100^{\circ} \mathrm{C}$; and $115^{\circ} \mathrm{C}$. The results of the analysis, as presented in Table 9, showed that: (a) turmeric simplicia has a greater curcumin content than white turmeric; (b) under the same conditions, white turmeric simplicia has an essential oil content, curcuminoid, demethoxy curcumin, and bis-demethoxy curcumin higher than turmeric.

TABLE IX. FUNCTIONAL COMPOUND CONTENT OF TURMERIC AND WHITE TURMERIC SIMPLICIA RESULTED FROM DRYING TEMPERATURE OPTIMIZATION

\begin{tabular}{|c|c|c|c|c|c|c|}
\hline \multirow[b]{2}{*}{$\begin{array}{c}\text { Simplicias } \\
\text { Type \& } \\
\text { Drying } \\
\text { Temperature } \\
\left({ }^{\circ} \mathrm{C}\right)\end{array}$} & \multicolumn{6}{|c|}{ Functional Compound Content (\%) } \\
\hline & 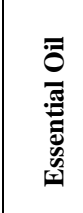 & 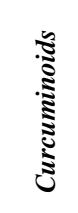 & 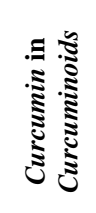 & 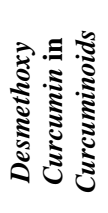 & 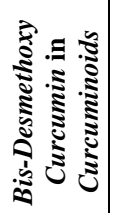 & 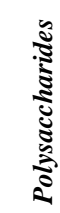 \\
\hline \multicolumn{7}{|l|}{ Turmeric } \\
\hline $70^{\circ} \mathrm{C}$ & 3.15 & 1.82 & 58.05 & 12.06 & 2.86 & \\
\hline $85^{\circ} \mathrm{C}$ & 3.02 & 1.31 & 56.52 & 11.41 & 2.62 & \\
\hline $100{ }^{\circ} \mathrm{C}$ & 2.69 & 1.22 & 54.18 & 10.46 & 2.08 & \\
\hline $115^{\circ} \mathrm{C}$ & 2.04 & 1.05 & 53.86 & 9.81 & 2.01 & \\
\hline \multicolumn{7}{|l|}{ White Turmeric } \\
\hline $70^{\circ} \mathrm{C}$ & 3.25 & 1.96 & 46.13 & 15.32 & 5.58 & 6.00 \\
\hline $85^{\circ} \mathrm{C}$ & 3.10 & 1.81 & 44.82 & 14.50 & 5.10 & 5.72 \\
\hline $100{ }^{\circ} \mathrm{C}$ & 2.81 & 1.30 & 43.51 & 14.47 & 4.35 & 5.60 \\
\hline $115^{\circ} \mathrm{C}$ & 2.20 & 1.26 & 42.84 & 12.36 & 4.15 & 5.42 \\
\hline
\end{tabular}

TABLE X. QUALITY STANDARD OF SIMPLICIA ISSUED BY MATERIA MED INDONESIA [17]

\begin{tabular}{|l|l|}
\hline \multicolumn{1}{|c|}{ Characteristic } & \multicolumn{1}{c|}{ Value } \\
\hline Water content & Max. 12\% \\
\hline Essential oil content & Max. 1.5\% \\
\hline Ash content & Max. 8.0\% \\
\hline Patogenic content & None \\
\hline Foreign material (impurities) & Max. 2.0\% \\
\hline
\end{tabular}

Furthermore, in order to obtain the operational conditions for the turmeric and white turmeric simplicia manufacture that have the best quality, has done the simplicia quality analysis using the standard set by Materia Med Indonesia [12]. Based on the optimization results, it is known that the best simplicia product is generated from the following operational conditions: (1) 1 minute washing time; (2) $0.15 \mathrm{~cm}$ slicing thickness; (3) oven-based drying; and (4) $115{ }^{\circ} \mathrm{C}$ drying temperature. The best quality of turmeric simplicia found to have contents of $2.04 \%$ essential oil; $1.05 \%$ curcuminoid; $53.86 \%$ curcumin; $9.81 \%$ demethoxy curcumin; and $2.01 \%$ bis-demethoxy curcumin. Meanwhile, white turmeric simplicia product with best quality contained $2.20 \%$ of essential oils; $1.26 \%$ curcuminoid; $42.84 \%$ curcumin; $12.36 \%$ demethoxy curcumin; $4.15 \%$ bis-demethoxy curcumin; and $5.42 \%$ polysaccharides.

\section{CONCLUSION}

The optimization results showed the effect of washing time, slice thickness, drying method, and temperature in water and functional compound content of turmeric and white turmeric simplicia produced. Increased washing time of raw materials has led to an increase in water content and decrease of simplicia functional compounds. In contrast to these conditions, the increase in the slice thickness of the raw material has led to an increase in water and functional compounds content of turmeric and white turmeric simplicia.

The optimization result of the drying method shows that the application of drying process using sunlight with black cloth intermediate has produced the turmeric and white turmeric simplicia with the highest water content, while the simplicia product with the lowest water content is obtained from the oven-based drying process. Furthermore, an increase in drying temperature has resulted in lower water content and reached the maximum when a drying temperature of $115^{\circ} \mathrm{C}$ is used.

The best quality of turmeric and white turmeric simplicia generated from production stage by (1) 1 minute washing time; (2) $0.15 \mathrm{~cm}$ slicing thickness; (3) oven-based drying process; and (4) $115{ }^{\circ} \mathrm{C}$ drying temperature. Turmeric simplicia product with best quality has a water content of $13.83 \%$ with $2.04 \%$ essential oil; $1.05 \%$ curcuminoid; $53.86 \%$ curcumin; $9.81 \%$ demethoxy curcumin; and $2.01 \%$ bisdemethoxy curcumin. Meanwhile, white turmeric simplicia product with best quality has a water content of $9.50 \%$ and $2.20 \%$ essential oil; $1.26 \%$ curcuminoid; $42.84 \%$ curcumin; 
$12.36 \%$ demethoxy curcumin; $4.15 \%$ bis-demethoxy curcumin; and $5.42 \%$ polysaccharides.

\section{ACKNOWLEDGMENT}

We would like to thank Directorate of Research and Community Service, Ministry of Research and Technology, Higher Education of the Indonesian Republic which has provided financial support through National Priority Research Programme, Masterplan of Acceleration and Expansion of Indonesia's Economic Development.

\section{REFERENCES}

[1] Z. Kalaycioglu, E. Torlak, G. Akin-Evingur, F.B.Erim, "Antimicrobial and physical properties of chitosan films incorporated with turmeric extract,” Int. J. of Biological Macromolecules, August 2017.

[2] B.Z. Hmar, D. Kalita, B. Srivastava, "Optimization of microwave power and curing time of turmeric rhizome (Curcuma Longa L.) based on textural degradation," LWT - Food Sci. and Technol., vol. 76, pp. 4856, March 2017.

[3] A.L. Santana, M.A.A. Meireles, "Coprecipitation of turmeric extracts and polyethylene glycol with compressed carbon dioxide," The J. of Supercrit. Fluids, vol. 125, pp. 31-41, July 2017.

[4] N. Laokuldilok, P. Thakeow, P. Kopermsub, N. Utama-ang, "Optimisation of microencapsulation of turmeric extract for masking flavor," Food Chem., vol. 194, pp. 695-704, March 2016.

[5] G. Asghari, A. Mostajeran, M. Shebli. "Curcuminoid and essential oil components of turmeric at different stages of growth cultivated in Iran," Res. in Pharmaceutical Sci., vol. 4(1), pp. 55-61, March 2009.

[6] R. Sahu, J. Saxena, "A brief review on medicinal value of Curcuma caecia,” Int. J. of Pharm. and Life Sci., vol. 4(5), March 2013.
[7] C. Kitamura, T. Nagoe, M.S. Prana, A. Agusta, K. Ohashi, H. Shibuya, "Comparison of Curcuma sp. In Yakushima with C. Aeruginosa and C. Sedoaria in Java by trn K gene sequence, RAPD pattern, and essential oil component," J. of Nat. Medicines, vol. 61(3), pp. 239-243, January 2007.

[8] T. Kokan, J. Tsumura, "Anti tumor protein-bound polysaccharides from Curcuma plants," Jpn Kokai Tokyo Koho JP 60 67, vol. 428 (85 67, 428) (CA 103:92834w), 1988.

[9] R. Paramawati, Mardison, S. Triwahyudi, and R.Y.Gultom, "Design and testing of horizontal type of mechanical rhizome chopper," Indonesian J. of Agriculture, vol. 3(1), pp. 39-44, 2010.

[10] M.L. Barek, M. Hasmadi, A.Z. Zaleha, and A.B.Mohd Fadzelly, "Effect of different drying methods on phytochemicals and antioxidant properties of unfermented and fermented teas from Sabah Snake Grass (Clinacanthus nutans Lind.) leaves,'International Food Res. J., vol. 22(2), pp. 661-670, 2015.

[11] J.P. Pertiwi. Evaluasi kinerja alat pengering simplisia menggunakan sumber panas sinar matahari dengan backup panas kompor biomassa untuk memenuhi standar kualitas simplisia jahe, Universitas Sebelas Maret, Surakarta, Indonesia, January 2015

[12] N. Kusumawati, M.A. Anggarani, Rusijono, P. Setiarso, S. Muslim "Product standardization of Ginger (Zingiber officinale Rosc.) and red ginger (Zingiber officinale var. Rubrum) simplicial through washing time, slice thickness and raw materials drying process optimization," Int. J. on Advanced Sci. Eng. Inf. Technol., vol. 7, pp. 15-21, 2017.

[13] J. Prasad, V.K. Vijay, G.N. Tiwari, V.P.S. Sorayan, "Study on performance evaluation of hybrid drier for turmeric (Curcuma longa L.) drying at village scale," J. Food. Eng., Vol. 75, pp. 497-502, August 2006.

[14] A. Borah, K. Hazarika, S.M. Khayer, "Drying kinetics of whole and sliced turmeric rhizomes (Curcuma longa L.) in a solar conduction dryer," Infor. Process. in Agriculture. Vol. 2(2), pp. 85-92, September 2015.

[15] B.K. Bala, "Solar drying of fruits, vegetables, spices, medicinal plants and fish: developments and potentials," [Proceedings of the international solar food processing conference], Indore, India, 2009. 